\title{
SMALL FARMERS AND CONVERSION: THE ROLE OF SOCIAL CAPITAL (EVIDENCE FROM MANGGARAI, FLORES, EAST NUSA TENGGARA, INDONESIA)
}

\begin{abstract}
Robert M.Z. Lawang
Research Cluster Rural Ecological Society, LabSosio, Faculty of Social and Politic, Indonesia University, Depok, Jawa Barat, 16424, Indonesia.

E-mail: robertmarkus925@yahoo.co.id

Citation: Lawang, R.M.Z. 2019. Small Farmers and Conversion: The Role of Social Capital (Evidence from Manggarai, Flores, East Nusa Tenggara, Indonesia). J. Asian Rur. Stud. 3(1): 48-61

Abstract: This article deals with the role of social capital in Manggarai on the basis of the following assumptions. First, the incapacity of the poor farmers to develop social capital themselves caused by external and internal constraints. Empowerment and policy approaches are primary in social capital formation. Second, combination of empowerment and policy approaches which seem to be relevant for problem solving. This article is based on field research where qualitative approach was used. Both farmers belonging to Ecopastoral and NonEcopastoral clusters have been developing social capitals for themselves used in their trajectories of conversion. The groups belonging to the clusters are important for further policy development through resource mobilization of social capitals own by government, civil society organization and market.
\end{abstract}

Keywords: Social capital formation; Eco pastoral cluster; Non-Eco pastoral cluster; Manggarai; Policy development

\section{Introduction}

This article deals with the role of social capital in conversion to organic farming. This convince however is only possible if the micro (individual), mezzo (group) and macro (Manggarain society) levels related to organic farm issues are made vertically and horizontally connected. The small rate of achievement in conversion since 2000 , which only about $0.05 \%$ of total 100,000 farmers, is resulted only from micro and mezzo interventions. According to Rogers (in Padel 2002), with only 50 organic farmers, the self-fulfilling prophecy (Merton 1948) of further conversion can be impossibly running in its own pace. Macro intervention is needed for more achievement. Governments of all levels have authority to develop policy regarding organic farming in a synergy approach (Woolcock and Narayan 2000, Woolcok 2002, Oliveira 2002), where bigger participation can be made possible (Putnam 1993).

There are three assumptions on which social capital analysis is based. Firstly, the incapacity of the poor to develop social capital necessary for social mobility. Empowerment approach is essential to solve this problem (Øyen, 2002; Bourdieu 
1986; Lewandowsky, 2008; Lawang 2018b). Empowerment approach is essential to solve this problem. Secondly, the lack of policy which enables the poor to develop social capital necessary for social mobility (Woolcock and Narayan, 2000; Woolcock, 2002; Oliveira, 2002). Thirdly, experiences have been teaching us many times in many ways that each of the approaches, despites its necessity, is still insufficient to facilitate the poor to foster mobility. Combination of both is believed to be more effective. This approach can be termed as Policy Based Empowerment (PBE) or Empowerment Based Policy (EBP), depending on point where it is started from.

\subsection{Theory of Social Capital}

Let me start with a strong statement given by Øyen saying that 'The rosy picture that is presented of integration through social capital formation is in fact gloomy and unrealistic. If a majority of the poor are neither able to develop useful networks for increasing their own social capital on a large scale, nor given entry into those networks where social capital flourishes, how can social capital then be an efficient instrument for poverty reduction? (Øyen, 2002: 13-14). The question is why? The following answers are hypothetically reasonable. First, from the habitus point of view of the upper classes, vertical networking for social mobility developed by the outcasts is intentionally or unintentionally "blocked" if the networking will be resulting in their disadvantages (Bourdieu, 1984, 1986; Lewandowsky, 2008). Top-down distrust is highly characterizing the relationship. Second, from habitus point of view of the outcasts, vertical networking for mobility is "blocked" internally by themselves due to their incapability of doing relationship with upper layers (Bourdieu 1984, 1986). This is called as "getting by" in the terminology of Woolcock and Narayan (2000), or lack of self- confidence. Social exclusion becomes more severe resulted from external and internal constraints. If this is the case, one of among other solutions, is to develop policy aimed at empowerment and inclusive development as well in a simultaneous way which open a bigger participation in development (Putnam, 1993).

I have a strong conviction that empowerment is a matter of how to deal with real problems faced by the outcasts primarily related to their daily life which can be met in a sustainable manner. In the matter of organic farming, some considerations need to be mentioned here. First, organic farming must be somehow resulting in farmers' prosperity on one side and consumers' satisfaction on the other side. Farmers' prosperity can be achieved through the use of technology (friendly environmental), and the consumers' satisfaction can be gained from the quality of food produced and reasonable price. In the view of New Exemptionalism, not only farmers are exempted through the use of farming technology but also consumers as well (Mol and Spaargaren 2009). Mutual trust built between organic farmers and consumers is necessary for making conversion is sustainable. Minimum quality assurance (socially defined), reasonable prices are among other things which can be resulting in mutual trust. But what is certainly absent in training practice is dealing with threats coming occasionally from changing weather where none of the poor farmers has capacity to solve. I underline the criticism of Foster on this matter saying that planetary crisis is a global phenomenon which cannot be solved by single individual alone (Foster, 2012). Second, an agro-meteorological device has been made available for farmers residing in Indramayu West Java and Lombok to solve this problem. A number of 
extensive analysis and trainings have been conducted by Stigter and Winarno (2016) and Taqiuddin in Lombok (2017). The empowerment was carried out in what they call Science Field Shops. Farmers come to gather for "buying" and "selling" information related to climate change, by which farmers can take necessary actions in proper way. The problem however is the lack of government's commitment to support the innovation in a sustainable manner (Taqiuddin, 2017). Third, as far as organic farming is concerned, market is necessarily supplementary to civil society-state relation (Woolcock, 2002; Oliveira, 2002). For sustainability reason, market can connect production and consumption in a mutual benefit way. Synergy among them can be resulting in the sustainability of conversion (Woolcock and Narayan, 2000).

Synergy approach is a complicated one. The problem is dealing with resources contributed by government, civil society and corporations in a joint effort to develop policy and its implementation for an effective solution. The role of government in this relation is absolutely needed due to its capacity to issue regulation for broader civic participation in social development (Woolcock and Narayan, 2000; Putnam. 1993; Oliviera, 2002). Problems dealing with social distrust among sectors, corruptions, overlaps are among other things interfering coordination. Nevertheless, the issuance of Agricultural Ministerial Regulation (2016) regarding organic farming village with fixed target of 20 hectare each province each year, is a good point for making the best of the tripartite relation.

\subsection{Franciscan Ecology}

Franciscan Ecology (FE) is not a scientific enterprise. It is rooted in the way of life of simple man, devoting his life to absolute poverty, called Francis of Assisi a founder of OFM. He was born in late 1181 or early 1182. Inspired by Psalms in the bible, he believed that all creatures should praise God, and the people have a duty to protect and enjoy nature as both the stewards of God's creation and as creatures ourselves. On November 29, 1979, Pope John Paul II declared Saint Francis the Patron Saint of Ecology (en.wikipedia.org, 2018). His idea of ecology and way of life is primarily referred by Pope Francis in his book entitled LaudatoSi' (Francis, Pope 2015). By OFM, his legacy was institutionalized in Justice, Peace and Integrity of Creatures (JPIC) (2017), one of its divisions is Ecopastoral dealing with critical issues of farming in general. Pagal Ecopastoral was the first established by Indonesian OFM.

Saint Francis has a very fundamental way of looking at creatures in his time. The social milieu of 1200 s decades in which he lived, was not as degraded as it is in these days. In 1800s, Karl Marx observed an opposite condition where the integrity of the nature had been rifted in its metabolic system (called metabolic rift), which somehow destroyed the balance of nature (Foster, 1999). In a dramatic way, the metabolic rift thesis was developed in a planetary scope, called as planetary rift, which clearly shows a number of serious threats to the existence of the world and our living planet, unless a radical change is made (Foster, 2012). Seen this way, FE is much more radical than Marxist way of looking at the problem of environmental crisis. In the view of FE, humankind is as equal as other creatures living in this globe, that he called them as brothers and sisters (en.wikipedia.org, 2018). The nature of social structure consequently includes not only humankind, but also the other living 
creatures in general. This issue is central in environmental sociological debate between the pro capitalist or anthropocentrism (Mol and Spaargaren, 2009), and the pro eco-centrism concerning with the threats and limitation imposed upon by the changing weather (Foster, 2012). I do not discuss this theoretical controversy in details. Suffice it to say that FE has a similar assumption with eco-centrism.

The role of civil society in promoting organic farming in Indonesia was remarkable. Long before the establishment of Ecopastoral in 2000, and the Encyclical Letter Laudato Si' of Pope Francis in 2015, in May 7, 1984, Agatho Elsener a Franciscan priest of Capuchin established an institute called Yayasan Bina Sarana Bakti aimed at conversion development in terms of plot to convert farmers into organic farming (www.bsb-agatho.org, 2013).

\subsection{Conversion and institutionalization through the use of social capital formation}

Conversion has to do with three related levels. At micro level (individual farmers), it is dealing with habituation of related actions/behaviors necessary for organic farming such as organic fertilizer provision and farming itself. Without this habit, organic farming is impossible. At mezzo level, conversion has to do with typification of related behaviors of people of a bigger scope, without which organic farming is also impossible. Market supply of organic fertilizer and consumers' satisfaction are ends or goals to be anticipated by any farmers at individual level. At macro level, conversion has to do with societal level where value related to organic food and organic farming must be supported by consumers, market and government for the sake of sustainability. For a bigger target, macro approach is absolutely needed (Berger and Luckman, 1966).

In the principle of New Exemptionalism mentioned earlier, ecological and economic benefits resulted from the technological intervention are not only useful for individual farmers, but also for society at large. The role of government is very important in relating individual farmers and consumers through mutual trust in quality of food produced. In other words, social capital is needed for more conversion through vertical relation between farmers and consumers on one side and government on the other side.

Habituation, typification and institutionalization of conventional farming were developed simultaneously at three levels of farmers (micro), districts (mezzo) and state (macro) when Green Revolution approach was introduced in 1980s. Although the type of technology is different, the means - end schema is the same. Synthetic fertilizer and all related infrastructure and facilities were made available for supporting the process of change in farming (Priasto, 2015). It was remarkably successful because it was similar to Goffman's terminology of "total institution" where all horizontal and vertical chains of actions were focused on one goal achievement, namely national food security, and to some point of self- sufficiency in rice without import in $1985 \mathrm{~s}$. In short, the habituation, typification and institutionalization at macro level in this case worked in the logical principle of technology for production increase. In the case of organic farming, the process seems to be uncoordinated at national scale. 
Despite the achievement in institutionalization process in the field of conventional farming was remarkable, there was something missing in keeping the process maintained in its further trajectory. The "modern" farming institution constructed socially by the total involvement of farmers who were of great desire to improve social welfare by means of technological intervention, and the government's commitment to alleviate poverty of rural poor farmers, was not well maintained over several years after its amazing achievement in rice production in 1980s. Some analysts blame government for this unsustainability. I do believe however, that the unsustainability has been resulted from government policy which mostly based on project after project (project to project a project) on one side and farmers' attitudes which have been contaminated by a project culture in a boomerang way. Corruption at government level is transferred to civil societies, including farmers (Syahyuti, 2012). Eventually it has been resulting in a rampant corruption. I underline the conclusion of Woolcock and Narayan saying that 'neither the state nor societies are inherent ly good or bad'... (Woolcock and Narayan, 2000: 236). What was missing?

In Indonesia farmers are grouped into two separated organizations. One is called Water User Association (WUA), and the other is called Group of Farmers. Formerly WUA was coordinated under the Ministry of Public Works where water provision was the main concern, but later it was transferred to the Ministry of Agriculture because of its water service's concern. Is there any change in its development? Both Ministries are working on project basis. Although in its legal principle the association is formed by and for farmers in democratic way, in practice however they are formed when an irrigation project is launched either in terms of new construction or rehabilitation and other related project such as irrigation service fee. They disappeared when project was over. Unfortunately, it is repeated many times many years. The same is true for Group of Farmers. In short, the institutionalization process of both organizations does not work. Even more than that, an acute problem of inefficiency in governmental bureaucracy has been part of their organization.

I have a strong belief in the capacity of what is called gotong royong, a way of working which involves all stakeholders to develop policy and program in a participatory approach including in its implementation and evaluation. This approach is found in any communities around the country and kept functional to certain extents. In Manggarai the approach is called réjé lélé bantang cama a way of doing thing together in many aspects of life (Lawang, 1989/2004, 2018a). Réjé lélé is a traditional way of inviting and bantang cama refers to consensus. At community level the approach has its root in the social structure of Manggarai and been empowered for poverty alleviation (Lawang, 2018), called as communitarian view in the development perspective of Woolcock and Narayan (2000). At inter-community level - defined as village or Kecamatan in the terminology of administrative systems - the approach was used by government in the project called PNPM Pedesaan (national participatory program for rural development) which was modified for a bigger and larger common purpose such as transportation, road or other public facilities to mention a few (Lawang, 2018a). Again, this is the case where government has authority and power to modify local wisdom for a greater use, which is developed by Woolcock and Narayan in their institutional view of social capital (2000). In the case of conversion to organic farming, the problem is much bigger and larger, due to the involvement of consumers 
becomes necessary. In order to achieve more target in the future, réjé lélé bantang cama must be used at farmers and district levels. Since réjé lélé bantang cama has to do with horizontal relation, its combination with district level can be a synergy of vertical line (Woolcock and Narayan, 2000). Civil society organization- market thesis can be supported by local wisdom (Woolcock, 2002).

Organic farming has been practiced in sustainable way by a small number of farmers in Manggarai. Resources, network, mutual recognition and acquaintance available among them can be used for a broader purposes (Bourdieu, 1986; Bourdieu in Swartz, 2002) and improved in its capacity (Coleman, 1988). Although the synergy approach has a great number of challenges in its practice, I have a strong confidence in its capacity to mobilize more necessary resources for coping some farming problems coming from unexpected natural disasters, organic fertilizer supply, market absorption and appreciation in healthy food. The approach is possible if we rely on what kind of social capital has been functioning in conversion and what kind of social capital is to be done for keeping them sustained and taking part in further steps of conversion project.

For a policy development, converters need to be organized. For converters who are not organized, there is a need to organize them if their roles are significant for more conversion. In the terminology of Dahrendorf (1959), they are potential (quasi group or latent group) to be grouped for organizational purposes. There has no fundamental problem to group formation in self-fulfilling prophecy way (Merton 1948), because they have the same interests and experiences dealing with organic farming.

\section{Materials and Methods}

Purpose of the research was to examine three assumptions dealing with social capital formation through the use of empowerment approach, policy approach and combination of both. By this way the low rate of conversion to organic farming (about $0.05 \%$ in twenty years) can be described, and more target in the future can be expected through policy development regarding conversion.

Qualitative approach was used here due to its social construction character. Social capital formation has to do with mutual trust building among actors related to the capacity of technology to produce food organically, to yield increase, to consumers' satisfaction and it effect for further steps taken by farmers. The process has been taking place in a social structure which is enabling and constraining occasionally. The social structure is called Manggarai and in its farming development has been interfered by conventional ways which are mostly contradictory with organic farming. Shortly, conversion is a trust building process related to many actors (Newman, 2006).

The research was conducted in Pagal and Ruténg where most of the area of organic farms are found. Pagal is a capital city of Kecamatan Cibal, where OFM parish is located. OFM has been farming since 1950s

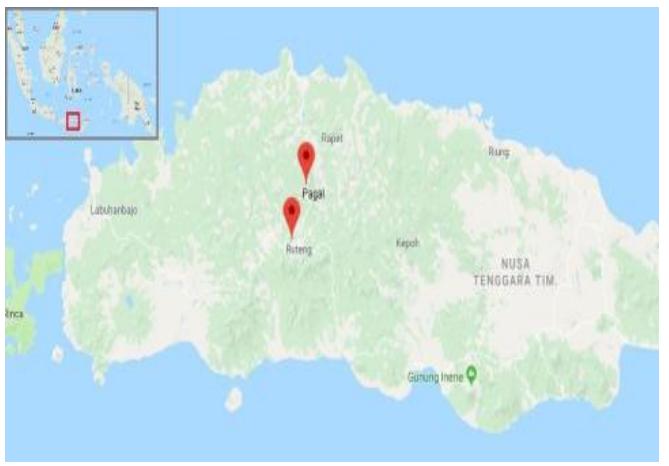


for household consumption. A decreasing yield due to the long use of synthetic fertilizer, was the reason for them to convert into organic farming in 1998.

After continuous good yields were achieved, they decided to establish Ecopastoral in 2000, equipped with training facilities for organic fertilizer development and its use in farming. A permanent complex for in-door activities anddormitory has been built and used since 2013. Many farmers coming from parishes over thedistricts of Manggarai, West Manggarai and East Manggarai, and even more from the other districts in East Nusa Tenggara province have been trained. Ruténg is capital city of Manggarai district, where independent farmers are residing (see map).

The notion of organic farming must be made clear. It is not standardized. It is organic due to the use of organic fertilizer, substituting synthetic fertilizer used before. I underline the terminology of Maier et al. for this kind of practices, which they call quasi organic farming (Maier et al., 2005). Its capacity to increase yield higher than before and its impacts on soil and economic improvement for farmers are much more important than standardization.

Methods were developed to gather information related to the three approaches mentioned before. Firstly, the issues dealing with empowerment approach was understood through discussion, interview and observation made on the training center managed by Ecopastoral. All staffs gave me a much attention on the issues I put forward. I have met them more than four times in different occasions. Besides, I interviewed government staff responsible for demonstration plot located in Kénda, 5 $\mathrm{km}$ northward of Ruténg, and farmers residing around the project. Secondly, problems encountered by organic farmers in their trajectories of conversion were collected through discussion, observation on their sites of farming, interview and photography. About fifteen farmers residing in Pagal and Ruténg were involved independently or collectively in my interview and discussion. I have met them more than three times in different occasions. Thirdly, some consumers happened to be coming in interview or coming for buying vegetable were involved and willing to give information I need.

Data and information were categorized along the assumptions mentioned before. Most of data related empowerment approach I got from Ecopastoral and Kénda staffs and farmers related to them. For policy approach and PBE or EBP I got much understanding of my long discussion with some rational farmers residing in Ruténg.

I underline the need of multidisciplinary approach to get a comprehensive understanding of the problems related to conversion. The disciplines relevant to this issue are agronomy, politics, administration, economy and of course sociology itself (Lamine et al., 2009). Due to technical and financial reasons, the multidisciplinary approach was not used here.

\section{Results and Discussion: The Role of Social Capital in Conversion}

Discussion is organized along the problems of conversion approach, social structured emerged, quasi tripartite relation and policy based empowerment as my recommendation. 


\subsection{SMOF Approach and Social Capital}

Ecopastoral is an approach combining FEin one side, and Manggarain local wisdom called réjé lélé bantang cama in the other. In the eyes of farmers, Ecopastoral is primarily considered as a catholic institution which is trusted due to the known virtues of commitment, quality of service, sincerity to mention a few. This is a generalized trust embedded in Ecopastoral as it is also embedded in other catholic organization in Manggarai. This generalized trust is strengthened its legitimation through the use of réjé lélé bantang cama in the whole trajectory of Ecopastoral hitherto. It is remarkably noted that the establishment of Ecopastoral in 2000, was informally co-founded by OFM and farmers.

Most of Manggarain farmers are smallholders of less than 0.5 hectare, big family, poor and less educated. For efficacy reasons, Ecopastoral developed an approach which I call self- made organic fertilizer (SMOF) the way they provide organic fertilizer for substitution. By this way, local practice of farming is more independent and freed from unnecessary dependence upon external supply. Considering the farmers' background mentioned earlier, Ecopastoral developed two separated plots for organic farming. One for irrigated paddy and the other for vegetables. The plots were also based on a widely known adage saying that "a good example has in itself power to convert people in efficient and effective way, as it was true in the past when irrigated farming came to Manggarai for the first time". Plots are major parts of training development. Manuals for organic fertilizer development are resulted from plot practices and skill development. The SMOF approach is used for both plots. The goal is to demonstrate the farmers that the good yield in quantity and quality is the result from the use of organic fertilizer. Five to six tons paddy per hectare have been achieved over years. The quality of vegetables produced, is of the best ever according to permanent consumers.

All these achievements are resulted from an organizational capability of Ecopastoral which has been supported by a number of professional staffs, working on permanent basis under an OFM priest leadership recruited periodically after a couple of years of service. But what is the result?

From the trainee point of view, two main categories can be distinguished, namely the successful and the failed (temporarily or permanently). The first category consists of lay people who farm as livelihood and religious community living in convents of nun or priest who farm organically for household consumption. This category has a growing self- confidence in theirown capacity to farm organically. In all cases, they have been independently developing all mechanism to solve problems related organic fertilizer development, farming and market issues. But socially and psychologically they consider themselves as part of Ecopastoral for skills and mutual trust they developed during training period. The second category consist of trainees who failed to convert, but still have attachment with Ecopastoral.

For a purpose of comparative analysis I call Ecopastoral and the trainees as Ecopastoral cluster in more social and psychological rather than physical sense. This notion is necessary for mapping purpose of policy development. 


\subsection{FOF Approach and Social Capital}

FOF is abbreviation of fabricated organic fertilizer, a method used by rational farmers residing in Ruténg and the suburb. They are basically economic oriented, developing norm for self-discipline and trustful relation with consumers and sometimes with suppliers of organic fertilizer. According to them, without those virtues it is impossible to sustain in a circumstance where market is open wide to external supplies. Medium they have been developing for a future "cooperative" is really helpful for poor farmers to make farming facilities available on time. A mutual trust is being built, commitment to take part in joint efforts to solve problems, is growing steady.

They have been also developing cooperation with local government to design a better market place for organic food, and to network hotel managers for organic food supply. Like their counterparts in big cities who are trying to develop on line market, they want to make the best of it for economic and practical reasons.

In 2014 Local government was inspired by Ecopastoral to develop a demonstration plot in Kénda, $5 \mathrm{~km}$ northward of Ruténg city. Kénda was eligible because there are many conventional farmers living there who can be converting through a good example. Despite the problems of market and willingness to change are still unsolved, the local government has been developing another eleven demonstration plots for the same purpose. Financial support on annual basis for staffs working in professional ways contribute the plots to sustain. Like rational farmers, FOF approach is employed in farming.

This category of farmers is called Non-Ecopastoral cluster, due to their social and pshychological attachment with Ecopastoral.

\subsection{Conversion Based Structure}

Social structure in the analysis of social capital is essential. From the practices so far, a social structure based on conversion is emerging and has its own right.

Conversion Based Social Structure in Manggarai

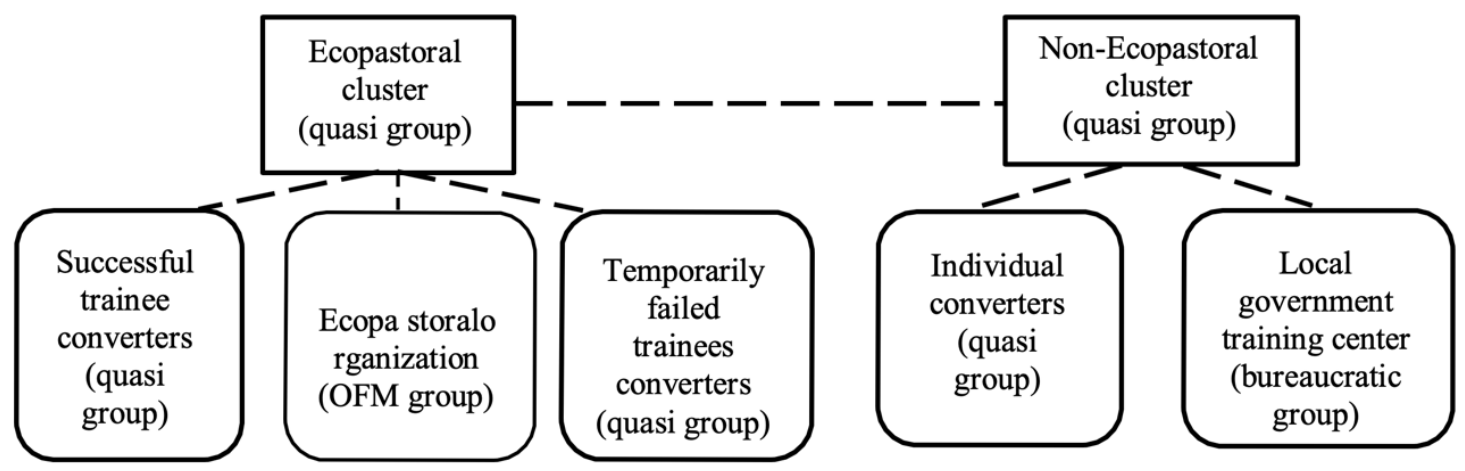


How far the above structure can be potentially functional for social capital formation, the following analysis seems to be relevant. First, at micro and mezzo levels, the successful trainee converters (or the Ecopastoral cluster) and individual converters (of Non-Ecopastoral) can be grouped or assigned to take more role in the future conversion. The grouping and the assignment can be increasing their stock of social capital, in terms of self-confidence, mutual trust, integration and reciprocal norms. Second, even in the case of the temporarily failed converters trained by Ecopastoral, they can also grouped or assigned to take part in the future conversion with more trainings. By the grouping and assignment, social capital they have from their relationship with Ecopastoral, can be increased on the basis of little selfconfidence they have. Third, both Ecpastoral organization and the local government organization can be assigned to take role for a bigger responsibilities and bigger benefits. At macro level, both Ecopastoral and Non-clusters can be grouped for a bigger responsibility. Under the spirit of local wisdom and their experiences, a good policy can be developed.

\subsection{Quasi Tripartite Relation}

Rather than dealing with policy development, local government has been too much concentrating on demonstration plot development which has been developed by Ecopastoral. There is no wrong with the policy, but it is basically unnecessary duplication which takes much time and money. Essentially, the role of civil society organization is taken by government. Market issues which are central to converters in general are not dealt by government caused by its concentration on plot issues. Nevertheless, the lessons from the plots can be useful for policy development.

\subsection{Policy Based Empowerment}

Policy for more conversion in the future can be developed on the following basis. First, Ecopastoral approach has been resulting in a "manual" training that can be developed for duplication reasons. Second, quality of organic food produced by Ecopastoral can be improved for standardization purposes, by which a broader market especially with respect to organic food supply for Hotel and tourist restaurants can be developed. Trainings for standardization seem to be reasonable. Third, the opportunity for organic farming village development funded by central government can be taken for new plots development through the use of empowerment approach developed by SMOF and FOF ways. Fourth, market in sense of physical notion, is needed for institutionalization of organic farming habits on one side and of the consumption pattern on the other side. Generalized trust in organic food is the main requirement for sustainable development. All these are only possible if local government take initiative for resource mobilization owned by all actors involved in organic farms. 


\section{Concluding Remarks}

A number of concluding remarks I need to make clear. First, from evidence practices the notion of social capital formation refers to a mutual trusts developed through organic practices in Manggarai since 2000, and trust-building developed by local government, elements of civil society and market regarding organic farming, organic food and consumption. The existing social capital can be used for the next social capital formed in tripartite relation. Second, a multidisciplinary research needs to be designed for a more comprehensive understanding of organic farm issues and its effective solution. A policy based empowerment or empowerment based policy should be based on multidisciplinary study.

\section{References}

Alrøe, Hugo F, John Byrne and Leigh Glover, 2005. Organic Agriculture and Ecological Justice: Ethics and Practice. In Global Development of Organic Agriculture: Challenges and Promises, Eds., N. Halberg, H.F. Alrøe, M.T. Knudsen and E.S. Kristensen. CAB International, pp 76-108. http://orgprints.org/4307/4/4307-Alroe_4p_revised-ed.pdf, Viewed 20 June 2018

AOI, 2015. Statistik Pertanian Organik Indonesia. Aliansi Organis Indonesia, Bogor.

Badan Ketahanan Pangan Kementerian Pertanian. 2015. Data Statistik Ketahanan Pangan

Berger P.L, and T. Luckmann, 1966. Social Construction of Reality. Penguin Books Ltd. http://perflensburg.se/Berger\%20social-construction-of-reality.pdf., Viewed 20 June 2018

Bourdieu, P, 1984. Distinction: A Social Critique of The Judgement of Taste. Harvard University Press, Cambridge.

Bourdieu, P., 1986. The Forms of Capital. In Handbook of Theory and Research for the Sociology of Education, Eds., J. Richardson. New York: Greenwood, pp: 241-258

BPS. 2011. Statistical Year Book of Indonesia 2011. BPS, Indonesia.

Coleman, J.S. 1988. Social Capital in the Creation of Human Capital. The American Journal of Sociology, Vol. 94, Supplement: Organizations and Institutions: Sociological and Economic Approaches to the Analysis of Social Structure (1988), pp. S95-S120 pp. S95-S120. http://www.jstor.org/stable/2780243, Viewed 12 February 2017

Dahrendorf, Ralf, 1959. Class and Class Conflict in Industrial Society. Stanford University Press, Stanford.

Direktorat Jenderal Tanaman Pangan. 2016. Petunjuk Teknis Pengembangan Desa Pertanian Organik Padi Tahun 2016, Kementrian Pertanian, Indonesia

Else Øyen, Else, 2002. Social Capital Formation: A Poverty Reducing Strategy?. In Social Capital Poverty Reduction: Which Role For The Civil Society Organizations And The State?. Paris: United Nations Educational, Scientific and Cultural Organization: Paris, p: 9-12. http://unesdoc.unesco.org/images/0013/001325/132556e.pdf., Viewed 8 November 2017 
FAO. 2017 Papers Submitted to the International Conference on Organic Agricutlure and Food Security, FAO, Rome, Italy. http://www.fao.org/tempref/docrep/fao/meeting/012/ah953e.pdf, Viewed 20 June 2018

Foster, J. B. 1999. Marx's Theory of Metabolic Rift. American Journal of Sociology, 105(2): 366-405. https://www.jstor.org/stable/10.1086/210315, Viewed 7 March 2017

Foster, J. B. 2012. The Planetary Rift and the New Human Exemptionalism: A PoliticalEconomy Critique of Ecological Modernization Theory. Organization Environment, 25(3): 211-237. DOI: 10.1177/1086026612459964. http://journals.sagepub.com/doi/abs/10.1177/1086026612459964, Viewed 12 February 2017

Halweil, Brian. 2006. "Can Organic Farming Feed Us All?". http://www.worldwatch.org/node/4060. Viewed 7 March 2017

Holmes, Bob. 1993. Can sustainable farming win the battle of the bottom line?. Science, Vol. 260, Issue 5116, pp. 1893-1895. DOI: 10.1126/science.260.5116.1893

Huber, J, 2009. Ecological modernization: Beyond scarcity and bureaucracy. In The Ecological Modernization Reader, Eds., A. P. J. Mol, D. A. Sonnenfeld., \& G. Spaargaren. London: Routledge, pp: 42-55

IFOAM, Year. "Principles Of Organic Agriculture". https://www.ifoam.bio/en/organiclandmarks/principles-organic-agriculture.

Jahi, Chappell, M, 2007. Shattering Myths:Can sustainable agriculture feed the world?. Food First Institute for Food and Development Policy, Vol. 13. Number 3, Fall $2007 . \quad$ https://foodfirst.org/publication/shattering-myths-can-sustainableagriculture-feed-the- world/, Viewed 21 January 2018

Lamine, Claire and Stephane Bellon. 2009. Conversion to Organic Farming: A Multidimensional Research Object at The Crossroads of Agricultural and Social Sciences, ouvertes.fr/hal-00886434/document, Viewed 21 January 2018

Lawang, Robert M.Z, 2018b. "Pembangunan dari Pinggir SebuahTantangan: Kasus Peternak Ayam Potong Skala Kecil di Manggarai Raya". Flores Pos April 26.

Lawang, Robert M.Z, 2004. Kapital Sosial dalam Perspektif Sosiologik. FISIP UI Press, Depok.

Lawang, Robert M.Z, 2004. Stratifikasi Sosial di Cancar, Manggarai Flores Barat. FISIP Press, Depok.

Lawang, Robert M.Z, 2018a. Social Poverty in Two Extreme Cases in Manggarai - East Nusa Tenggara Province. Presented in SWB Conference Yogyakarta (unpublished)

Lewandowsky, Joseph D. 2008. On Social Poverty: Human Development and the Distribution of Social Capital. Journal of Poverty, 12(1): 27-48.

Maier, Jürgen et al., 2005. Organic Farming: A Contribution to Sustainable Poverty Alleviation in Developing Countries. Forum Environment \& Development Am Michaelshof, Bonn.

Mayrowani, Henny, 2012. Pengembangan Pertanian Organik di Indonesia. Forum Penelitian Agro Ekonomi 30(2):91-108.

Merton, Robert K. 1948. The Self-Fulfilling Prophecy. The Antioch Review 8(2):193210. https://www.jstor.org/stable/4609267, Viewed 21 January 2018 
Miller, Donald E, 2011. Civil Society and Religion. In The Oxford Handbook of Civil Society, Eds., Michael Edwards. Oxford: Oxford University Press, pp 197-208.

Mol, A. P. J. and Spaargaren, G., 2009. Ecological Modernization: Theory in Debate. In Ecological Modernization Around The World, Eds., A. P. J. Mol and D. Sonnenfeld. London: Frank Cass, pp: 17-49

Neuman, W. Laurence, 2006. Social Research Methods, Qualitative and Quantitative Approaches, Sixth Edition. Pearson Education, London.

News Related to Organic Farming Statistics in Europe: http://www.organiceurope.net/europe-statistics/europe-statistics-news.html, Viewed 20 June 2018

Oliveira, Miguel Darcy de, 2002. Citizen Participation and Social Capital Formation: Resource Mobilisation for Social Development - the Experience of ComunidadeSolidária in Brazil. In Social Capital Poverty Reduction : Which Role For The Civil Society Organizations And The State? Paris: United Nations Educational, Scientific and Cultural Organization:Paris,pp: 13-18. http://unesdoc.unesco.org/images/0013/001325/132556e.pdf, $\quad$ Viewed 8 November 2017

Padel, Susanne, 2002. Conversion to Organik Farming: A Typical Example of the Diffusion of an Innovation?. European Society for Rural Sociology, Vol. 41, Issue 1, pp 40-61. https://doi.org/10.1111/1467-9523.00169

Peraturan Menteri Pertanian Nomor 64/Permentan/Ot.140/5/2013 Tentang Sistem Pertanian Organik. Kementrian Pertanian. .

Peraturan Menteri Pertanian Republik Indonesia Nomor 19/Permentan/HK.140/4/2015 tentang Rencana Strategis Kementerian Pertanian Tahun 2015-2019. Kementrian Pertanian.

Prakash, Sanjeev, 2002. Social Capital and the Rural Poor: What Can Civil Actors and Policies Do?. In Social Capital Poverty Reduction : Which Role For The Civil Society Organizations And The State?. Paris: United Nations Educational, Scientific and Cultural Organization: Paris, pp: 13-18. http://unesdoc.unesco.org/images/0013/001325/132556e.pdf,_Viewed 8 November 2017

Pugliese, Patrizia. 2001.Organic Farming and Sustainable Rural Development: A Multifaceted and Promising Convergence. European Society for Rural Sociology, Vol. 41, Issue 1, pp 112-130. https://doi.org/10.1111/1467-9523.00172

Putnam R., 1993. Making Democracy Work: Civic Tradition in Modern Italy. Princeton University Press, Princeton.

Putnam, R. D, 2000. Bowling Alone The Collapse and Revival of American Community. Simon \& Schuster, New York.

Rundgren, Gunnar, 2005. Organic Agriculture and Food Security. IFOAM, Germany

https://www.ifoam.bio/sites/default/files/organic_agriculture_and_food_security printcop y.pdf, Viewed 24 June 2018.

Sezgin, Zeynep, 2012. Ecological Modernization: A Viable Option for A Sustainable Future?. Marmara Journal Of European Studies, 20(1):219-245. 
Siti Jahroh, 2010. Organic Farming Development In Indonesia: Lessons Learned From Organic Farming In West Java And North Sumatra. In ISDA 28 June - 1 Juli, France. http://hal.cirad.fr/hal-00521832/document, Viewed 20 June 2018

Stigter, K dan Y.T. Winarto, 2016. Pelatihan Bagi Pelatih-Penyuluh dan Petani Pemandu untuk Memandu "Warung Ilmiah Lapangan". Agroment Vision, University of Indonesia (unpublished).

Swartz, David L, 2002. The Sociology of Habit: The Perspective of Pierre Bourdieu. Winter,Volume

22 ,

Supplement.https://researchrepository.ucd.ie/bitstream/10197/3848/1/

The Phenomenolog y_of_Habit.doc.

Syahyuti, 2012. Pengorganisasian Diri Petani dalam Menjalankan Agribisnis di Pedesaan: Studi Lembaga dan Organisasi Petani dalam Pengaruh Negara dan pasar. Unpublished. Doctoral Dissertation, University of Indonesia, Indonesia.

Tagiuddin, Moh. 2017. Struktur Sosial dalam Proses Perubahan: Implikasi Pembelajaran Agrometeorologi dalam "Warung Ilmiah Lapangan" pada Dinamika Struktur Sosial Petani Sawah Tadah Hujan di Pulau Lombok. Unpublished Doctoral Dissertation, University of Indonesia, Indonesia.

Tahun 2014, Kementrian Pertanian, Indonesia Standarisasi Nasional.

The General Office of JPIC Curia Generalis OFM Cap., 2017. Handbook of Just ice, Peace, and Integrity of Creation (JPIC). General Office of JPIC, Rome. https://www.ofmcap.org/images/docs/news/jpic_handbook en.pdf

Woolcock, Michael, 1998. Social Capital and Economic Development: Toward a Theoretical Synthesis and Policy Framework. Theory and Society, 27(2):151-208.

Woolcock, Michael, 2002. Social Capital in Theory and Practice: Reducing Poverty by Building Partnerships between States, Markets and Civil Society. In Social Capital Poverty Reduction: Which Role For The Civil Society Organizations And The State?. Paris: United Nations Educational, Scientific and Cultural Organization: $\quad$ Paris, pp: 13-18. http://unesdoc.unesco.org/images/0013/001325/132556e.pdf, Viewed 8 November 2017

Woolcock, Michael, 2011. Civil Society and Social Capital. In The Oxford Handbook of Civil Society, Eds, Michael Edwards. Oxford: Oxford University Press, pp. 197-208.

http://www.mestradoprofissional.gov.br/sites/images/mestrado/Docs/EDWARDS Michel

Woolcock, Michael, Narayan, Deepa. 2000. Social Capital: Implications for Development Theory, Research, and Policy. The World Bank Research Observer, 15(2):25-249. 